\title{
Research on the Development and Countermeasures of MICE Tourism in Jilin Province
}

\author{
Liguang Zhao \\ School of Taxation \\ Jilin University of Finance and Economics \\ Changchun, China 130117
}

\author{
Mingju Liu \\ Yantai School of Business Administration \\ Jilin University of Finance and Economics \\ Changchun, China 130117
}

\author{
Shanhua Jin \\ Yantai School of Business Administration \\ Jilin University of Finance and Economics \\ Changchun, China 130117
}

\begin{abstract}
MICE tourism has been a hot topic in the tourism industry in recent years. And it is also an important direction for the development of tourism. This paper analyzes the development of MICE tourism in Jilin province. And it also points out the problems in the development process of MICE tourism in Jilin province. And it also puts forward the countermeasures and measures of sustainable, healthy and rapid development of MICE tourism in Jilin province.
\end{abstract}

Keywords-Jilin province; MICE tourism; development and countermeasures

\section{INTRODUCTION}

Nowadays, the market information is changing rapidly. The science and technology has made progress with each passing day. And the market economy is mature. MICE tourism is an important part of the tourism development in Jilin province. Although it has just started, it has got the widespread concern. And the development prospect is broad. What are the problems with the current MICE tourism? How will MICE tourism develop in the future? It needs us to solve this problem urgently.

\section{THE MICE TOURISM OVERVIEW}

\section{A. The Concept of MICE Tourism}

MICE tourism is generally used to organize seminars, international conferences, trade fairs and other official activities, and kinds of exhibitions, fairs, cultural and sports activities, science and technology exchange activities to carry out comprehensive new forms of tourism. In simple terms, it is the tourism activity with the visit as the main purpose. The exhibition industry and tourism industry continue to develop and integrate. And then, they have made the MICE tourism. Its main body is the exhibition industry. It plays a leading role in the MICE tourism. The tourism industry and the exhibition industry interact with each other.

Fund Project: National Natural Science Foundation of China (Project No.: 41401146); Science and Technology Development Project of Jilin province (201502040NY). Department of Education Project of Jilin province. (JJKH20170140SK)
There is indivisible relationship between the tourism industry and the exhibition industry. And tourism is the basis for the development of MICE tourism. It will integrate the exhibition industry and the tourism organically. The guests can visit the exhibition. At the same time, they can have a visit on the local tourism resources. They also can participate in more activities to extend the duration of stay in the destination. Then the visitors will participate in more service industry. Thus, it brings the effect of low cost and big economic effect. MICE tourism can be divided into broad and narrow sense. In a broad sense, the purpose of MICE tourism is based on conferences and exhibition tours, including conference tours, exhibition tours, and other work tours and reward tours. In narrow sense, it provides conference and exhibition activities with the exhibition venues and tourism-related services. And then, it would obtain certain income from the economic activities.

\section{B. The Characteristics of MICE Tourism}

1) Consumption ability is strong, and the consumption level is higher: The people participating in the exhibition activities usually have certain positions. Compared to ordinary tourists, they have independent consumption awareness. And they also have a higher income. The consumption level is relatively high. Therefore, they will pay more attention to the terms of quality, service, characteristics and other factors. In terms of high consumption, large scale, strong ability and high demands, exhibition visitors aren't the same as ordinary tourists.

2) They will stay for long time, and they have more traveling opportunities: The timetable for MICE tourism depends on the specific time of the exhibition activities. And these activities will generally take long time. And it provides an opportunity for the people who participate in the exhibition activities to carry out recreational activities after work. The representatives, especially ecdemic representatives, often are busy with the work. So they are strongly eager to participate in the exhibition. At the same 
time, they can get physical and mental relaxation. And they can have the visit to the nearest tourist scenic area.

3) The exhibition has certain plan, and they wouldn't be affected by the seasons: Due to the particularity of the exhibition tourism activities, the requirements for the purchase, the food, the hotel and entertainment activities of the people who participate in the exhibition activities must be well planned in advance. Due to the natural conditions of tourism and the imbalanced distribution of tourist leisure time, the general tourism has clear seasonal variation. And the MICE tourism wouldn't be affected by the climate and the season. It is the unique characteristics of the MICE tourism. Due to the characteristics of the tourism industry, it has made up for the imbalance. Also, the revenue of offseason tourism has increased. And it also promotes the stable development of tourism services industry.

4) The economic efficiency is high, and the capability for achieving foreign exchange is strong: MICE tourism can be said that it is the extension product from the exhibition industry to the tourism industry. It has both the properties of the exhibition products and tourism products. And it has close contact with transportation, catering, accommodation, shopping, entertainment and other industrial sectors. And then, it has formed a strong industry linkage of MICE tourism. It can bring great business opportunities and wealth to the host venues, and also can improve the local economic benefits. And the international conferences and exhibitions can attract more overseas businessmen. At the same time, it also has the ability to earn foreign exchange.

\section{THE DEVELOPMENT AND PROBLEMS OF MICE TOURISM IN JILIN PROVINCE}

\section{A. The Development of MICE Tourism in Jilin Province}

In recent years, the exhibition industry of Jilin province is developed from the initial stage to high-speed development stage. To sum up, it has gone through three stages. In the first stage, it was from the reform and opening up. And it began to host Changchun International Film Festival once every two years since 1992. And the exhibition industry of Jilin province began to enter the initial stage. Each festival will be accompanied by the corresponding economic and trade activities of the fairs and exhibitions. However, the enthusiasm of enterprises to participate in these activities isn't high. It is mainly led by the government. Changchun International Convention and Exhibition Center was built as a symbol of Jilin province. And the development of exhibition industry was into the initial stage. As a result of fixed exhibition venues, the number of exhibitions can reach more than twenty or thirty each year. The representative is the Changchun Commodity Fair. Although the scale is limited, the participation of enterprises has improved. Most companies think that it is a favorable opportunity to promote and demonstrate some things. The exhibition in Jilin province will also enter the stage of high speed development, which is represented by the major exhibitions such as automobile exposition, agricultural fair, film festival and education exhibition. The number of exhibitions has been increasing year by year. With an average increase of nearly 20 exhibitions per year, some of which are already wellknown in China. According to statistics, the number of exhibitions in Changchun has been increased from 97 in 2005 to 286 in 2013. And the direct income is 3.6 billion yuan. Also, the revenue of the other related industries is 37.8 billion yuan. At present, the number of exhibitions is the sixth in the country. The exhibition venue is the eighth in the country. Changchun exhibition has entered the first echelon of the national exhibition industry. In addition, it has host the Yanbian National Border Trade Negotiation successfully for 10 times from 2005 to 2014. Yanbian has a good geographical location and unique geographical advantages. It can promote the economic cooperation and exchanges at home and abroad. And the economic construction of Yanbian has achieved fruitful results. And unique ethnic style and image of Yanbian can leave unique impression on the participants. It can increase its popularity. The Rime Ice and Snow Festival of Jilin province and the Grape Festival of Tonghua have also made contribution for the development of MICE tourism in Jilin province.

\section{B. The Problems of MICE Tourism in Jilin Province}

1) The lack of professionals: According to the survey of people who work for the MICE tourism in Jilin province, most of the practitioners don't have the systematic study and training. Therefore, the quality of practitioners isn't high. And it lacks the professionals. Due to the lack of the professionals, it lacks the originality in exhibitions of Jilin province. And it is also the important reason for the difficulties of the development of the exhibitions in Jilin province.

2) With government intervention, it lacks management and accurate positioning: Due to the history and systems, the exhibition tourism in China is mainly dominated by the government, which directly interferes with the specific operation of the exhibition and tourism activities. Most of the major conferences or exhibitions are organized by the government in Jilin province with strong administrative participation. Therefore, the market-oriented development of exhibition tourism has been restricted. To a certain degree, the enthusiasm of enterprises participating in exhibition and tourism activities has been limited. Government-run exhibition is mainly responsible for the host right and policy support. It needn't to arrange all the things. And it needn't to participate in the construction of management system and service system of MICE tourism, and the cooperation between the exhibition and the tourism departments, etc. Therefore, excessive government intervention isn't good for the development of MICE tourism. And it would have no clear management organization. Then, the economic benefits of the whole exhibition activities would be affected. It may prevent the rapid development of MICE tourism.

3) The lack of the integration of exhibition industry and tourism: The way of MICE tourism to attract tourists is through various exhibitions, fairs and meetings. The core of 
exhibition tourism is tourism. It can meet the needs of catering and accommodation through various exhibition activities. And then, it should strive for the needs of shopping, sightseeing and entertainment. Therefore, the exhibition enterprises should cooperate with the tourism enterprises. However, from the perspective of the situation of Jilin province at present, the service projects of tourism enterprise are mainly concentrated in the food, accommodation and traffic. And there is deficiency in shopping and entertainment areas. Especially, there is no active cooperation between the exhibition enterprises and the tourism enterprises. So, it has missed good market opportunities and economic benefits.

\section{ANALYSIS ON ADVANTAGES AND DiSADVANTAGES OF MICE TOURISM IN JILIN PROVINCE}

\section{A. The Advantages}

1) Superior geographical location and convenient transportation: It is located in the middle of northeast China. Also, Jilin province is located in the northeast region, which consists of Japan, Korea, Korea, Russia, Mongolia and northeast China. And it has the geographical advantage of international cooperation. In terms of traffic conditions, Jilin has become major transportation junction in northeast China. And it has formed safe and convenient three-dimensional transportation network for highway, railway and aviation security. The railway runs through the four corners of the world. And it has formed a cross. The highway is radiated, connecting dozens of large and medium-sized cities in and out of the province. At the same time, there are good communication conditions.

2) Rich tourism resources: Jilin province has rich and unique tourism resources. With distinctive features of landscape, several cities in the province have been designated as excellent tourist cities in China. Moreover, Yanbian of Jilin province is the main habitation of Korean nationality. And it has unique tourism resources. Jilin province has many high quality tourist attractions and scenic spots. And it also has formed a better tourism product system. The tourism resources of Jilin province include: local landscape, water area landscape, climate landscape, relics and remains, biological landscape, buildings and facilities, tourist commodities, human activities. It can be said that it is a big province with tourism resources. Its representative tourism resources include Changbai Mountain, Jilin Rime, Changchun Movie Wonderland, and Korea historical sites and so on.

3) Improved infrastructure: The infrastructure construction of major cities in Jilin province is relatively good. It has good industrial base, strong technical force and scientific education development. In Jilin province, there are main conference and exhibition facilities: Changchun international exhibition center, Yanji international exhibition center, Jilin exhibition center, Tonghua exhibition center, Songyuan exhibition center. The cities of
Jilin province have its representative exhibition facilities and perfect infrastructure to provide services for exhibitions, conferences, and tourism, accommodation, catering and sports events. It also has the ability to undertake large-scale international exposition and international conference, BBS and national trade fair.

4) The advantages of winter weather: China's exhibitions are mainly in the period from May to September. However, the unique winter climate in Jilin province is conducive to the development of exhibition and tourism activities in winter. For instance, Rime and Snow Tourism Festival is in Jilin. Ice and Snow Festival is in Changchun. It is conducive to develop the environmental conditions in Jilin province. And then, the slack season of the exhibition would turn into the high season. And it is good for the development of exhibition tourism.

\section{B. The Disadvantages}

1) The lack of professionals in exhibition tourism: Human resources are the core and soul of knowledge economic competitiveness. And the key to the development of the exhibition industry lies in the good human resources. However, there is a gap between Jilin province and the advanced provinces in terms of the degree of specialization and the quality of relevant staff. Most practitioners come from other industries and lack professional training. Therefore, they lack professional knowledge and experience. They can't satisfy the demands of participants. Thus, they have to reduce the service level. And it will bring negative impact on the overall image of the exhibition industry.

2) The lack of professional management system: Several cities in Jilin province have already established the convention and exhibition management office to manage the exhibition activities. However, it hasn't achieved the professional pattern of division. To form mature exhibition market, it still has a gap. It is due to the lack of excellent talents and professional exhibition service organizations. Due to the lack of industry associations and management of the exhibition industry, the marketization degree isn't high. And the dispersion and waste of the resources is heavy.

3) The lack of development and marketing: In the process of exhibition tourism, Jilin province lacks the overall publicity and marketing ability. It is difficult to form broad brand effect. On the one hand, most of host companies are limited in their own abilities and scales. And they haven't actively cooperated with other tourism agencies and enterprises in marketing activities. On the other hand, the exhibition management department hasn't fully played its role. 


\section{ON THE DEVELOPMENT AND COUNTERMEASURES OF EXHIBITION TOURISM IN JILIN PROVINCE}

\section{A. In Management System (Transformation of Government Functions)}

The exhibition tourism in Jilin province has entered the preliminary stage of improvement. The government should change its functions, reduce micro-interference, and turn to macro-control and strengthen the guidance. The government should provide good relevant laws and regulations and policies. It should fully play the guiding and supporting role of the government. And it is the fundamental guarantee of the development of MICE tourism. Then, it can make the development of MICE tourism healthy and orderly. However, the guidance here isn't about hosting. The government should shift from the role of the specific exhibition to the role of the overall regulation. The government mainly focuses on exhibition venues and corresponding infrastructure. It should improve the services, and establish scientific exhibition approval system. And then, the exhibition company and exhibition industry association would actively participate in the development plan of exhibition tourism.

\section{B. The Talent Cultivation}

The development of exhibition tourism and the lack of professionals are common problems in the exhibition industry. It would not only affect the exhibition activities, but also the development of exhibition tourism to have professionals. The exhibition and tourism development in Jilin province is late. And there are few professional education institutions to cultivate the professionals. At present, many universities in Changchun have established the course of tourism management. However, only several colleges and universities have opened the course of exhibition tourism. Therefore, in the aspect of education, it should establish the corresponding courses, which should pay attention to the training of talents with professional knowledge and comprehensive ability. And it also can combine theory with practice. Then, it may train excellent exhibition talents. In addition, it is also important to train employees within the enterprise to cultivate flexible talents. And the internal functions of the organization should be constantly adjusted according to the development of exhibition tourism.

\section{The Brand Marketing}

1) To strengthen publicity and marketing: The external publicity and marketing are important parts in the rapid development of exhibition tourism. It can create better conditions for the development of exhibition tourism. Therefore, Jilin province also needs to strengthen its publicity and marketing. In order to strengthen the publicity and marketing, it should do the following things. First, it should fully understand the exhibition tourism in Jilin province. And it can make the market analysis and determine the target market. And then, it can focus on effective propaganda.

Secondly, it can make full use of various marketing methods. And it can use news, radio and other media to conduct marketing. Also, it can use the Internet to have quick and extensive publicity. Thirdly, it can actively participate in the travel fairs in national and regional level and other publicity and marketing activities. Fourthly, it can actively combine the exhibition enterprises with the tourism enterprises. And it also should integrate resources to design tourism routes for exhibition tourists. During Changchun automobile exposition, the travel agency has made full use of the cultural atmosphere of "motor city", Changchun FAW and other industrial tourism resources. It has developed many tourism products with the strong characteristic of automobile exposition. And these products have also met the demands of the market.

2) To establish brand awareness: The brand becomes the soul of the development of exhibition tourism industry. Branding is conducive to strengthening market competitiveness and avoiding the waste of resources. And it should focus limited funds on efficient and influential key markets. The government should strengthen the construction of stadiums and supporting facilities, and plan for the construction of pavilions. It should be scientific. Also, it should avoid the dispersion and small scale. With the professional and branding development, it can improve the construction of the hardware facilities of the entire city. To highlight the key points and reasonable layout is important. It should avoid low-level repetition construction. And it can establish long-term brand development strategy. Jilin province should find out the exhibition location according to economic conditions, geographical location, traffic environment, industrial production base and the developed degree of business flow. With the accurate positioning, it can keep the development of the exhibition tourism. At the same time, multinational exhibition companies have invaded the convention and exhibition market of China by brand exhibition transplantation in recent years. Jilin province can also establish exhibition recognition system. It can register the name and logo of the brand and other intellectual property rights. So, the exhibition would be protected.

3) To highlight the features of the product: The scale of the development of the exhibition tourism in Jilin province must be adapted with the current scale of regional economic development. According to the characteristics of social resource and condition and the market environment, it should make overall and long-term planning. The exhibition industry should be one part of pillar industries. And it should formulate corresponding policies and measures to support its development. It should use positive fiscal policy to help the development of the exhibition of various industries. It can support the innovative exhibitions with policy subsidies. Also, it should encourage enterprises to develop the brand exhibition with the development of the city industry. To a certain degree, it can reduce the negative impact of the development of exhibition tourism in Jilin province with the characteristics. And it can also improve economic and social benefits.

4) To develop overseas markets: In order to expand visibility and influence, MICE tourism in Jilin province 
should vigorously carry out international cooperation and communication through the way of "going out, and come in". At the same time, it can understand the development trend of exhibition tourism both at home and abroad. On the one hand, it should fully learn from foreign advanced experience, such as advanced foreign exhibition concept, mature management experience, and new exhibition standards of well-known international exhibition of "peopleoriented, professional services", etc. On the other hand, it can actively participate in the international conferences and exhibition organizations to communicate with international exhibition organizers and attract them to make the exhibitions in Jilin province.

\section{Market Environment}

1) To regulate market competition: The improvement of market environment and benign development need formal and orderly market competition. To avoid vicious market competition, Jilin province can set up market competition mechanism of the exhibition industry and breed the main body of the exhibition industry through the laws and regulations of the government and the norms of the industry association. It also can establish the normal order of market and establish exhibition investment evaluation system and credit system through self-discipline behavior of member enterprise to achieve self-discipline and self-coordination of the enterprises. Then, it can evaluate the cost and benefit of each exhibition. Through the implementation of the evaluation system, it can achieve the qualification of the main body of outstanding enterprises. And then, it can cultivate the main body of the market faster. Also, it can create good atmosphere for industrial development. With the implementation of the protection of intellectual property rights, it can avoid vicious competition.

2) To improve service quality: Jilin should also take full advantages of the advanced experience of foreign exhibition tourism in developed cities. And it can improve service quality and carry on the concept of people first. The improvement of services is not only to strengthen the construction of business services, the establishment of the post office, the special line transportation and other hardware facilities. It should also establish the related service providers, legal consultant institutions and other service facilities to improve software services. And it can provide better services for the exhibition. Also, it should improve the quality of service personnel. At the same time, it is important to improve the quality of the citizens, including cultural accomplishment, moral cultivation and the international language environment. And it should implement the national projects to jointly safeguard the image of Jilin province.

\section{E. Regional Cooperation}

It is of great significance for the exhibition and tourism market of Jilin province to deal with the cooperative relations between government, association and enterprises.
At present, the MICE tourism industry association of Jilin province is composed of the exhibition association and conference and incentive travel association. The cooperation of two associations can help the exhibition and tourism docking in another level in Jilin province. However, the data of the establishment of the two associations is different. And they belong to different departments. The development of the association isn't balanced. And the cooperation requires the unification of the competent departments. However, the establishment time of the two associations is different, different departments are different, the development of the association is not balanced, and the cooperation of each other requires the unification of the competent departments. In addition, the cooperation between the association, government and enterprises needs the advantages of the development of the exhibition tourism association. And the separation of the government and enterprises can help enterprises become the real subject of market. The government should delegate the responsibilities to the departments, and withdraw its domination of the exhibition tourism market. And then, the exhibition tourism industry association should organize and supervise the market, implement government policies and guide the development of the market.

\section{F. To Improve the Operation Mode}

The exhibition venues in Jilin province are short of power. And it would affect the development of the whole exhibition tourism industry in Jilin province. The exhibition area is small. The exhibition venue is dispersed. And the surrounding facilities are not perfect. So, some high-degree and large-scale exhibition projects are difficult to join in these activities. In view of the existing venues and exhibition venues under construction, Jilin province should integrate the facilities around the exhibition, and optimize the mode of operation of the convention and exhibition venues. It should connect the convention and exhibition center with urban commercial circle to develop the exhibition tourism.

\section{CONCLUSION}

As an important part of urban tourism, MICE tourism is highly valued by many cities at home and abroad. Although the MICE tourism in Jilin province has just started, it has a broad development prospect. Jilin province should transform government functions and roles in the management system. It should improve the management level of relevant departments and cultivate outstanding professional talents in the training of talents. It also should establish brand awareness, and highlight product characteristics in brand marketing. And it can strengthen publicity and marketing to explore overseas markets. It should regulate market competition in market environment. And then, it can improve service quality. It should strengthen cooperation and division in the relevant industries of government, exhibition industry and tourism in regional cooperation to achieve winwin results. In terms of improving the operation mode, it can strengthen the peripheral facilities and optimize the operation mode of the venues. And the development of exhibition tourism in Jilin province can be further improved. Jilin must develop the exhibition tourism economy, and attract 
merchants at home and abroad to make investment in this country. And it can inject new vitality into the economic development of Jilin province. Only in this way, Jilin can go to the world.

\section{REFERENCES}

[1] Liu Mingguang. SWOT analysis and development and countermeasures of MICE tourism in Jilin province [J]. Journal of Jilin Business and Technology College. 2009 (4).

[2] Liu Mingju, Yuan Fang. On the study of tourism resources [J]. Taxation and Economy, 2016 (1).

[3] Shi Subing. Analysis of social environment of exhibition industry in Jilin province [J]. Youth and Society. 2013 (36).

[4] Li Yingzhou, Jiang Yan. A review on the concept of MICE tourism [J]. Travel Forum. 2011 (2).

[5] Zhang Le. Study on the competitiveness of urban MICE tourism [D]. Nanjing: Southeast University. 2011

[6] $\mathrm{Xu}$ Feifei. On the economic development of Yanbian exhibition industry [D]. Yanji: Yanbian University. 2012.

[7] Wang Baolun. Exhibition operation and management [M]. Beijing: Peking University Press. 2006.

[8] Wang Zhao. Optimization of the development mode of MICE tourism-A case study of Changchun [J]. China Business. 2011 (28).

[9] Wu Sainan. Discussion on the development of MICE tourism in China [J]. Grand View Weekly. 2013 (5). 